\title{
PENERAPAN POSITIF DAN NEGATIF UNTUK MENINGKATKAN KEDISIPLINAN SISWA SMP LENTERA HARAPAN LAMPUNG TENGAH DALAM MAPEL IPS
}

\author{
Jossapat Hendra Prijanto ${ }^{1}$, Agnes Jumarta Gulo² \\ Diterima 4 April 2018, Dipublikasikan 9 Mei 2018 \\ CPenulis (2018)
}

\begin{abstract}
Discipline is an important aspect that every student should have, to achieve the learning objectives. Discipline, however, is often found as a problem in the classroom. This problem was found in grade VIII SMP Lentera Harapan Lampung Tengah students in Integrated IPS subjects. To solve the problem, in this research applied reward and punish to improve student discipline of class VIII. The reward form applied is in the form of praise, tape reward, and sign strengthening (certificate), while the punish form is the cutting of time and cost to be paid, with modifications called 'red box'. The methodology used in this research is Classroom Action Research method. The subjects of the study were students of class VIII with a total of 14 people, consisting of 11 men and 3 women. The results of the study on student discipline levels obtained from this study is the first cycle 69.8\%, 83.4\% and third cycle 93.8\%. It can be concluded that the application of reward and punish can improve the discipline in Integrated Social Science subjects in the seventh grade students of SMP Lentera Harapan Lampung Tengah.
\end{abstract}

\section{Keywords}

Discipline, Positive Reinforcement and Negative Strengthening

\section{PENDAHULUAN}

Marzano (2005), mengatakan bahwa kelas yang kondusif untuk proses pembelajaran adalah kelas yang dikelola dengan tepat. keberadaan peraturan dan prosedur yang didukung oleh hukuman dan penghargaan terkait dengan disiplin yang diterapkan oleh seorang pengelola kelas yaitu guru. Permasalahan kedisiplinan, peneliti temukan di sebuah kelas ketika menjalani masa praktikum mengajar di SMP Lentera harapan Lampung Tengah. Kelas VIII merupakan kelas dengan jumlah 14 orang siswa, terdiri atas 10 laki-laki dan 3 perempuan. Proses pembelajaran di kelas VIII sering sekali tidak berjalan sesuai dengan yang direncanakan oleh guru di dalam Rencana Pelaksanaan Pembelajaran (RPP) karena suasana kelas tidak kondusif untuk belajar. Adapun hal yang terjadi adalah 1) Peraturan dan prosedur yang ada tidak dapat dilakukan oleh siswa secara maksimal 2) Siswa sering menimbulkan kegaduhan 3) Siswa sering lalai untuk mengumpulkan pekerjaan rumah (PR). Perilaku tersebut menunjukkan sikap tidak disiplin siswa kelas VIII, dengan bersikap tidak sesuai dengan peraturan dan prosedur kelas yang telah diberlakukan dan ditetapkan oleh sekolah. Untuk memecahkan permasalahan kedisiplinan di kelas VIII SMP Lentera Harapan Lampung Tengah, peneliti menggunakan metode penguatan positif dan negatif selama proses pembelajaran di dalam kelas.

Arends (2008), mengatakan bahwa metode penguatan ini merupakan sebuah pendekatan perilaku yang sering menekankan tentang bagaimana mengontrol perilaku individu siswa. Metode ini memiliki pengaruh yang kuat terhadap pengaturan kelas, terkait pendisiplinan

1 FIP Universitas Pelita Harapan Tangerang Banten, jossapat.hendra@uph.edu

2 Sekolah Dian Harapan Holland Village Manado

Jurnal Teori dan Praksis Pembelajaran IPS Volume 3, No.1, 2018, 53-58 ISSN 2503-5307 
siswa dalam proses belajar mengajar. Thompson (2007) juga mengatakan bahwa pengaturan kelas yang maksimal menjadi kekuatan bagi guru untuk menyatakan kepada siswa bahwa perilaku baik merupakan hal yang serius di dalam proses pembelajaran. Oleh karenanya, setiap guru bertanggung jawab melakukan disiplin di dalam setiap kelasnya, karena disiplin memiliki tujuan bagi diri setiap siswa untuk mendewasakan dan memperbaiki diri menjadi lebih baik. Terlebih lagi, Brummelen (2006) menjelaskan tujuan disiplin adalah membuat siswa menjadi pribadi yang berkarakter sesuai dengan jalan-Nya, karena disiplin menjadi kesempatan untuk mengarahkan siswa dalam hal berjuang melawan nilai-nilai moral yang telah banyak mengalami degradasi.

Disiplin adalah kepatuhan untuk menghormati dan melaksanakan suatu sistem yang mengharuskan orang tunduk pada keputusan, perintah atau peraturan yang diberlakukan bagi dirinya sendiri. (Lemhanas, 1997, h. 12). Menurut Prijodarminto (1994, h. 23) Disiplin adalah suatu kondisi yang tercipta dan terbentuk melalui proses dari serangkaian perilaku yang menunjukkan nilai-nilai ketaatan, kepatuhan, kesetiaan, keteraturan dan atau ketertiban. Jadi, kedisiplinan adalah kondisi yang tercipta untuk menunjukkan nilai kepatuhan terhadap suatu keputusan atau peraturan.

Penguatan merupakan upaya untuk mendorong di ulanginya lagi (sesering mungkin) oleh pelaku tingkah laku yang dianggap baik. (Prayitno, 2009, h.145). Penguatan positif dan negatif membuat individu (dalam hal ini peserta didik) menjadi senang dan oleh karenanya ia mengulangi perbuatannya yang dianggap baik.

\section{METODE}

Metode penelitian yang digunakan peneliti yaitu Penelitian Tindakan Kelas (PTK) dengan model penelitian Kemmis dan Mc Taggart. Penelitian Tindakan Kelas (PTK) adalah suatu tindakan yang dilakukan oleh peneliti dalam usaha untuk memahami apa yang sedang terjadi, sambil terlibat di dalam proses perbaikan dan perubahan (Hopkins, 1993 dalam Wiriaatmadja, 2009). Sementara itu, model penelitian Spiral Kemmis dan Mc Taggart merupakan salah satu model penelitian dengan sistem spiral refleksi diri yang dimulai dengan rencana, tindakan, pengamatan, refleksi dan perencanaan kembali sebagai sebuah proses untuk memecahkan masalah (Trianto, 2011).

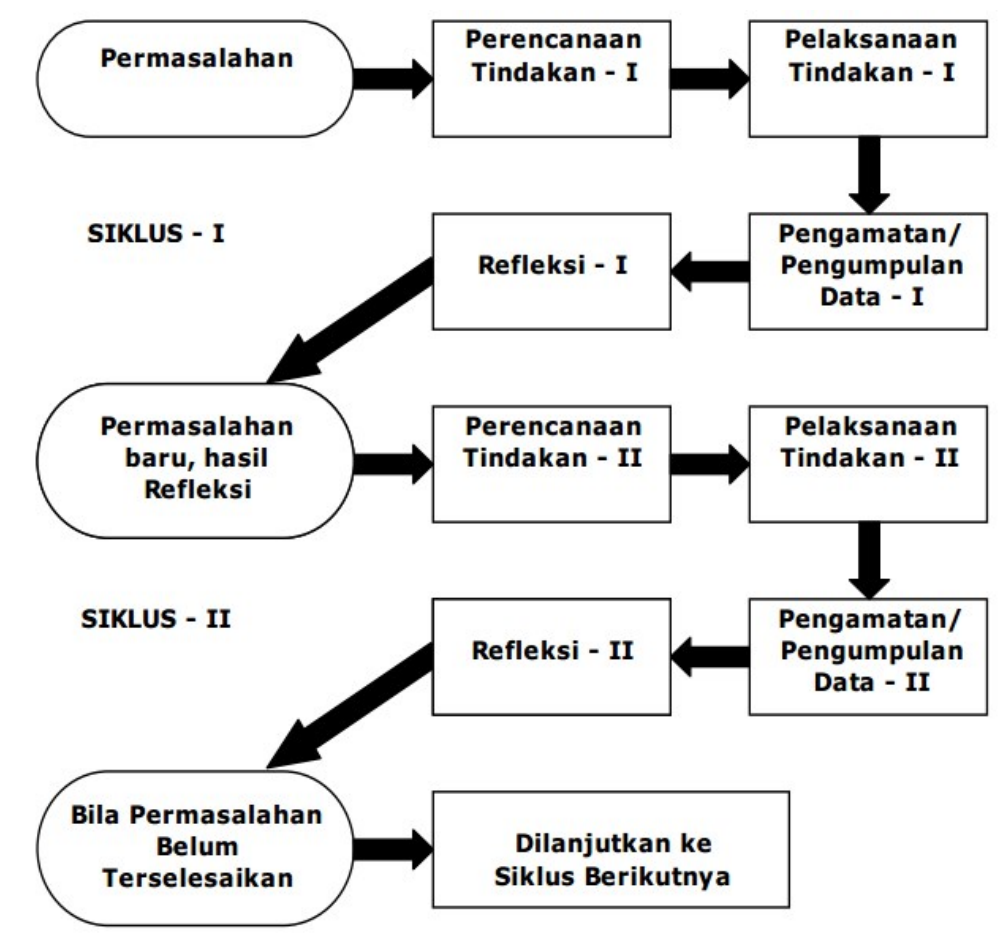

Gambar 1. Pola Siklus PTK (Sumber: Trianto, 2011) 


\section{HASIL DAN PEMBAHASAN}

Pengolahan data yang sudah didapatkan, Peneliti menggunakan konversi nilai hasil untuk menganalisis dan menginterpretasi data penelitian yaitu konversi nilai menurut Tampubolon (2014), perhatikan tabel 1. Menurut Tampubolon (2014), indikator keberhasilan kualitas proses pembelajaran dan perbaikan perilaku siswa, minimal berada pada kategori B/“baik". Berdasarkan konversi interval nilai di atas, maka peneliti menggunakan indikator keberhasilan siklus sebagai dasar peneliti untuk melanjutkan dan menghentikan siklus berada pada titik 6180 dengan kategori "baik". Di samping itu, peneliti menggunakan sebuah angka persentase pencapaian keberhasilan siklus yaitu $75 \%$. Kriteria ini berdasarkan teori yang telah dijabarkan oleh Djamarah \& Zain (2006), mengenai tingkat keberhasilan proses belajar mengajar, dengan $75 \%$ berada pada tingkat baik. Apabila telah mencapai 75\% taraf keberhasilan minimal, maka proses pembelajaran dapat dilanjutkan. Sementara apabila tidak mencapai $75 \%$, maka harus dilakukan perbaikan karena belum mencapai tingkat keberhasilan minimal yang telah ditentukan.

Tabel 1. Konversi Nilai Hasil Penelitian Tampubolon

\begin{tabular}{ccc}
\hline Interval Nilai & Kategori & Makna \\
\hline $81-100$ & A & Sangat baik \\
$61-80$ & B & Baik \\
$41-69$ & C & Cukup baik \\
$21-40$ & D & Kurang baik \\
$0-20$ & E & Sangat tidak baik \\
\hline
\end{tabular}

Sumber : (Tampubolon, 2014, hal. 39)

Penelitian ini menggunakan triangulasi data, dengan peneliti menggunakan beberapa instrumen untuk memperoleh data keberhasilan siklus penelitian. Adapun yang menjadi instrumen utama penelitian adalah lembar observasi guru pengamat (mentor). Sementara, instrumen pendukung antara lain lembar angket siswa, lembar wawancara mentor, lembar wawancara siswa, dan refleksi peneliti. Perhatikan tabel 2. untuk hasil dari keberhasilan indikator kedisiplinan siswa yang didapatkan dari penerapan penguatan positif dan negatif.

Tabel 2. Keberhasilan Indikator Kedisiplinan Siswa

\begin{tabular}{lllllll}
\hline & Ind 1 (\%) & Ind 2 (\%) & Ind 3 (\%) & Ind 4 (\%) & Ind 5 (\%) & Kedisiplinan (\%) \\
\hline Siklus 1 & 62 & 75 & 48 & 71 & 93 & 69,8 \\
Siklus 2 & 81 & 86 & 69 & 100 & 81 & 83,4 \\
Siklus 3 & 93 & 93 & 95 & 100 & 88 & 93,8 \\
\hline Rata-rata & 78,7 & 84,7 & 70,7 & 90,3 & 87,3 & $\mathbf{8 2 , 3}$ \\
\hline
\end{tabular}

Keterangan Tabel 2:

Ind 1: ketertiban siswa selama proses pembelajaran

Ind 2: hubungan positif siswa dengan guru dan teman

Ind 3: menjalankan peraturan dan prosedur

Ind 4: ketepatan waktu

Ind 5: pengumpulan pekerjaan

\section{Indikator Ketertiban Siswa}

Siklus 1 diperoleh angka persentase $62 \%$ dari lembar observasi guru pengamat (mentor) dan $67 \%$ dari angket siswa. Hal ini menunjukkan bahwa ketertiban siswa pada siklus satu sudah tergolong baik. Namun Sikap siswa yang kurang disiplin, beberapa siswa tidak mampu mengendalikan diri untuk tetap menjaga ketertiban kelas sehingga suasana kelas menjadi kondusif.

Siklus kedua, ada peningkatan angka persentase yang diperoleh dari lembar observasi guru pengamat sebesar $81 \%$ dan angket siswa $76 \%$. Ini menunjukkan bahwa siswa menggunakan dan merespon prosedur serta peraturan yang berlaku di dalam kelas dengan baik, terkhusus di dalam penerapan prosedur hand signal. 
Siklus ketiga, indikator mengalami peningkatan dengan hasil yang diperoleh melalui lembar observasi sebesar 93\% dan angket siswa 76\%. Pada siklus ketiga ini, observasi mentor menunjukkan angka persentase bermakna sangat baik, sementara angket siswa bermakna baik. Secara rata-ratanya, indikator ini berhasil mencapai target yang telah ditentukan oleh peneliti.

\section{Indikator Hubungan Positif Siswa dengan Guru dan Teman Sekelas}

Siklus pertama, diperoleh angka persentase sebesar 75\% dari lembar observasi guru mentor dan 76\% diperoleh dari lembar angket siswa. Hal ini menggambarkan bahwa siswa memiliki hubungan positif antara guru dan teman kelas lainnya. Hanya saja, di dalam penyampaian berkomunikasi, siswa perlu dilatih lagi untuk berani menyampaikan kesulitan-kesulitan yang dihadapi ketika proses pembelajaran.

Siklus kedua, dari lembar observasi guru pengamat diperoleh angka persentase sebesar $86 \%$, bermakna sangat baik dan angket siswa $76 \%$ bermakna baik. Hal ini menunjukkan bahwa hubungan positif telah terbangun di dalam kelas dengan baik, dengan siswa telah mampu berkomunikasi kepada guru dan teman kelas dengan bahasa dan cara yang benar. Akan tetapi, permasalahan mengenai keberanian siswa di dalam menyampaikan kesulitan yang dihadapi di dalam kelas masih berada pada persentase $71 \%$.

Siklus ketiga, dapat dilihat terjadi peningkatan angka persentase, dengan perolehan angka persentase dari lembar observasi guru pengamat (mentor) adalah sebesar 100\% dan angket siswa adalah sebesar 93\%. Kedua angka persentase ini berada pada posisi 81-100 dengan bermakna sangat baik. Hal ini menunjukkan bahwa prosedur dan peraturan kelas telah dijalankan dengan baik. Siswa juga telah berani untuk menyampaikan kesulitan yang dihadapi selama proses pembelajaran berlangsung.

\section{Indikator Menjalankan Peraturan dan Prosedur yang Telah Disepakati}

Siklus pertama, diperoleh angka persentase sebesar $48 \%$ dari lembar observasi guru pengamat (mentor) dan $75 \%$ dari lembar angket siswa. Akan tetapi, pada pernyataan mengenai perilaku siswa dalam menjalankan peraturan dan prosedur kelas, perolehan angka persentase adalah sebesar $64 \%$ - 71\%, dengan keterangan belum mencapai angka persentase keberhasilan yang telah peneliti tentukan. Ini menunjukkan bahwa siswa tidak mampu menjalankan peraturan dan prosedur yang telah disepakati di kelas dengan baik, meskipun penguatan telah diterapkan.

Siklus kedua, terjadi peningkatan yaitu diperolehnya angka persentase sebesar $69 \%$ dari lembar observasi mentor dan $76 \%$ dari lembar angket siswa. Jika diperhatikan, terdapat perbedaan persentase yang diperoleh dari kedua instrumen ini. Lembar observasi mentor menunjukkan angka 69\% dengan makna tidak baik, yang berarti bahwa siswa tidak disiplin karena belum menjalankan peraturan dan prosedur kelas sesuai dengan harapan guru. Sementara itu, lembar angket siswa menunjukkan angka $79 \%$ yang menunjukkan siswa menjalankan peraturan dan prosedur kelas telah meningkat dari siklus sebelumnya.

Siklus ketiga, dilihat peningkatan terhadap hal ini yaitu diperolehnya angka persentase sebesar 95\% dari lembar observasi mentor dan 91\% dari lembar angket siswa. Hal ini menunjukkan bahwa pada siklus ketiga ini, siswa telah menjalankan peraturan dan prosedur kelas dengan baik.

\section{Indikator Ketepatan Waktu Memasuki Kelas}

Siklus pertama, diperoleh angka persentase dari lembar observasi mentor yaitu sebesar $71 \%$ dan $76 \%$ diperoleh dari angket siswa. Hal ini menunjukkan bahwa siswa di kelas VIII secara umum telah memasuki kelas sebelum guru memasuki ruangan, hanya saja masih ada beberapa siswa yang belum menjalankan peraturannya. 
Siklus kedua, terlihat peningkatan dari siklus sebelumnya, dengan perolehan angka persentase $100 \%$ dari lembar observasi mentor dan $88 \%$ dari angket siswa. Hal ini menunjukkan bahwa seluruh siswa telah memasuki kelas sebelum guru memasuki ruangan kelas.

Siklus ketiga, diperoleh angka persentase $100 \%$ dari lembar observasi mentor dan $95 \%$ dari angket siswa. Hal ini menunjukkan bahwa siswa telah memasuki ruangan kelas sebelum guru memasuki ruangan kelas, sehingga setiap alokasi waktu yang telah diberikan berjalan sesuai yang telah direncanakan.

\section{Indikator Ketepatan Waktu Pengumpulan Pekerjaan Rumah}

Siklus pertama menunjukkan hasil yang baik dengan perolehan angka persentase sebesar 93\% dari lembar observasi mentor dan 75\% dari angket siswa. Hasil ini berada pada posisi baik dan sangat baik yang menandakan telah mencapai angka persentase keberhasilan yang telah ditentukan oleh peneliti.

Siklus kedua terjadi penurunan hasil persentase dengan $81 \%$ dari lembar observasi mentor dan $61 \%$ dari angket siswa. Perolehan persentase pada pernyataan lembar observasi mentor menunjukkan 57\% siswa di dalam kelas yang telah mengumpulkan PR dan 43\% siswa yang tidak mengumpulkan PR. Hampir setengah dari anggota kelas tidak mengumpulkan PR. Hal yang sama juga ditunjukkan oleh hasil angket siswa, dengan perolehan persentase sebesar $64 \%$.

Siklus ketiga, terlihat peningkatan pada indikator ini dengan perolehan $88 \%$ dari lembar observasi mentor dan $75 \%$ dari angket siswa. Hal ini menunjukkan bahwa siswa telah mengumpulkan PR tepat pada waktunya. Peneliti mengapresiasi siswa yang telah mengumpulkan PR tepat waktu sehingga dapat menjadi motivasi bagi yang belum untuk mengumpulkan PR tepat pada waktunya.

Siklus pertama, angka persentase yang didapat adalah sebesar $75 \%$ dan $74 \%$ dari angket siswa. Angka ini menunjukkan penguatan positif dan negatif di dalam kelas dengan baik, ditunjukkan dengan perolehan angka persentase sebesar 75\%,dan 74\% dari angket siswa.

Siklus kedua, terlihat peningkatan dengan perolehan persentase sebesar $79 \%$ dan $74 \%$. Hal ini sudah cukup baik dengan menjelaskan bahwa penerapan penguatan positif dan negatif telah dilakukan guru dengan konsisten dan adil.

Siklus ketiga, angka persentasenya adalah $86 \%$ dan $81 \%$, di mana berada pada posisi $81-100$ dengan makna sangat baik dan telah mencapai target keberhasilan yang telah ditentukan peneliti. Ini menunjukkan bahwa kedisiplinan siswa di dalam kelas telah membaik dengan penerapan penguatan positif dan negatif yang konsisten dan adil di dalam kelas.

\section{SIMPULAN}

Berdasarkan hasil penelitian yang telah dilakukan sebanyak tiga siklus, peneliti menyimpulkan bahwa penerapan penguatan positif dan negatif dapat meningkatkan kedisiplinan siswa kelas VIII SMP Lentera Harapan di Lampung Tengah. Peningkatan kedisiplinan dapat terlihat dari perolehan angka persentase dari siklus pertama yaitu $69,8 \%$, siklus kedua 83,4\%, dan siklus ketiga 93,8\%.

Peningkatan kedisiplinan siswa terjadi oleh karena penerapan penguatan positif dan negatif dilakukan dengan langkah yang tepat. Penerapan penguatan positif dan negatif diawali dengan penjelasan bentuk penguatan positif dan negatif yang diterapkan kepada siswa dan di sepanjang proses pembelajaran. Di dalam penerapannya, penguatan dilakukan dengan konsisten dan adil kepada setiap siswa di kelas.

Adapun beberapa saran yang dapat disampaikan adalah sebagai berikut:

1. Pengenalan karakteristik siswa yang akan diberlakukan bentuk penguatan positif dan negatif.

2. Mengetahui secara pasti penguatan positif dan negatif yang tepat dan efektif untuk mendisiplinkan siswa. 
58 Jossapat dan Agnes, Penerapan Positif dan Negatif untuk Meningkatkan Kedisiplinan ...

3. Pada awal pembelajaran, sebaiknya bentuk penguatan positif dan negatif perlu disampaikan dan dijelaskan dengan rinci kepada siswa. Jika perlu, mintalah pendapat dan persetujuan siswa dalam penerapannya.

4. Penguatan positif dan negatif dilakukan secara konsisten dan adil kepada setiap siswa.

5. Penerapan penguatan positif dan negatif yang diberlakukan di dalam kelas juga disertai dengan penguatan verbal kepada siswa.

6. Berikan pemahaman kepada siswa mengenai latar belakang dan tujuan diberlakukannya penguatan positif dan negatif tersebut.

\section{DAFTAR PUSTAKA}

Arends, R. I. (2008). Learning to teach. Belajar untuk mengajar (terj.). Yogyakarta: Pustaka pelajar.

Capehart, J., \& Niles, L. H. (2012). Touching hearts, changing lives. Jakarta: Metanoia Publishing.

Djamarah, S. B., \& Zain, A. (2006). Strategi belajar mengajar. Jakarta: Asdi Mahasatya.

Djiwandono. (2002). Psikologi pendidikan. Jakarta: Grasindo

Fennema, J. (1997). Nurturing children in the lord: A study guide for teachers on developing a biblical approach to discipline. United States of America: Presbyterian and Reformed Publishing Co.

Hurlock, E. B. (2005). Perkembangan anak (terj.) (6th ed.). Jakarta: Erlangga.

Lemhanas (1997). Disiplin nasional. Jakarta: PT. Balai pustaka

Marzano, R. J., Marzano, J. S., \& Pickering, D. J. (2003). A handbook for classroom management that works. Alexandria, VA: Association for Supervision and Curriculum Development.

Marzano, R. J., Gaddy, B. B., \& Foseid, M. C. (2005). A handbook for classroom management that works. United States: Association for Supervision \& Curriculum Development.

Prayitno. (2009). Dasar teori dan praksis pendidikan. Jakarta: Grasindo.

Prijodarminto, S (1994). Disiplin kiat menuju sukses. Jakarta: Pradnya Paramita.

Seifert, K., \& Sutton, R. (2009). Educationa Psychology (2nd ed.). Switzerland: The global text project.

Tampubolon, S. (2014). Penelitian tindakan kelas. Jakarta: Erlangga.

Van Brummelen, H. (2006). Berjalan bersama Tuhan di dalam kelas. Jakarta: Universitas Pelita Harapan.

Wiriaatmadja, R. (2009). Metode penelitian tindakan kelas. Bandung: Remaja Rosdakarya. 